\title{
The Migration of Christian Youth to Pentecostal and Charismatic Churches in Ghana: Implications for Mission Work
}

\author{
Paul Kang-Ewala Diboro' \& Raymond Charles Ehiem² \\ ${ }^{1}$ Department of Theology, Christian Service University College, Kumasi Ghana. \\ ${ }^{2}$ Great Change Christian Centre, Adenta, Accra Ghana.
}

\begin{abstract}
Recently, it appears the centre of gravity of Christian youth worldwide has shifted from the traditional or historic mission churches to Pentecostal, Neo-Pentecostal and Charismatic churches. This global phenomenon is also seen in a migration among Ghanaian Christian youth from mission or mainline churches to Pentecostal and Charismatic churches. What accounts for their migration and what could be done to prevent such mass movement? This paper argues that there are many factors that may determine the migration rate of the youth from historic mission churches. Interviews and literature study were the approaches employed for gathering of data. The paper draws attention to the fact that retaining the Ghanaian Christian youth in mission churches has become a major concern in a pluralistic church environment in Ghana.
\end{abstract}

Correspondence:

Paul Kang-Wala Diboro

Email: pdiboro@csuc.edu.gh

Publication History Received 3rd September 2020, Accepted 25th September 2020, Published online 9th October 2020.

Key Words: Migration, Pentecostal, Charismatic, Historic Mission Churches, Youth

\section{INTRODUCTION}

Following the testimonies of the early Church immediately after Pentecost included reports that many were added to their number day by day and that their number increased (Acts $2: 47 ; 4: 4 ; 6: 7$ ). This numerical growth of the early Church was important to ensure its continued existence. It is without doubt that attendance to church services and programmes is key to determine and sustain Christian churches and fellowships. ${ }^{1}$ When church membership declines, there are fundamental and foundational lapses which are pointers to the fact that the health of that church has been compromised. ${ }^{2}$

Currently, it has been noted that some mission or historic ${ }^{3}$ churches around the globe have recorded low attendance to the extent that some have closed down. The global picture is grim, especially in the developed world. Between the years 2000 and 2017 in the United States of America, the Roman Catholic Church closed down 81 churches while the Evangelical Lutheran Church closed 150 churches after losing 200,000 members, majority of whom are youth, due to decline in attendance and drift to other churches. The United Methodist Church also closed 65 of its churches for similar reasons. ${ }^{4}$

Church growth in Africa, particularly Ghana, can best be described in the context of this study as "robbing Peter to pay Paul". That is, members of one church moving to another church. Recently, it appears there is a lot of internal migration of church membership especially the youth from one local church to another as compared with converts that join the local churches from different faiths (Islam, Traditional Religions and others). This has gained considerable attention by some scholars.

\footnotetext{
Donald K. McKim, More Presbyterian Questions, More Presbyterian Answers: Exploring Christian Faith (Westminster John Knox Press, 2011 ), 72.

2 Rick Warren, The Purpose Driven Church: Growth Without Compromising Your Message and Mission (Kaduna, Nigeria: Zondervan Publishing House, 1995), 86.

The terms, "mission," traditional" or "historic," churches are interchangeably used in the paper. John Kwabena Asamoah-Gyadu in his book African

Charismatics: Current Developments within Independent Indigenous Pentecostalism in Ghana considers these churches in the Ghanaian context as the older

Western churches referring to historic churches that are in line with the Roman Catholic and Protestant missions that established missions in Ghana from

the late fifteenth and nineteenth centuries. The Presbyterian (1828), Methodist (1835), Anglican (1904), and Roman Catholic (1482; 1880) churches fall

within this group. He describes these churches to follow the order of Western European missionary style interns of church buildings, pattern of

ministry,clerical accoutrements, liturgical forms and hymnody, creeds and infant baptism and confirmation as a unique identity of membership of these churches..

4 Gail Cafferata, "Respect, Challenges, and Stress among Protestant Pastors Closing a Church: Structural and Identity Theory Perspectives," Pastoral Psychology 66 no 3 (2017): 326.
} 
According to Larbi, "the numerical strength of the Pentecostal movement is found both with the classical Pentecostals and neo-Pentecostals. This trend has led one commentator to refer to the phenomenon as Pentecostal explosion. The movement has penetrated the very centre of the historic churches, as key figures come under the influence of the Pentecostals." ${ }^{5}$ Victor Counted shares the opinion that "in traditional churches today, it appears that youths' migration to Pentecostalism is already on-going and gradually attracting concern. On the other hand, church leaders in Pentecostal churches are progressively creating more flexible youth-driven frameworks." ${ }^{\prime \prime}$ This Pentecostal influence and penetration is seen in the movement of the youth from historic mission churches to Pentecostal and Charismatic churches in Ghana. Asamoah-Gyadu also points out that in Ghana "some churches are declining numerically and others are enjoying new leases of life in the face of challenges from the context that has become religiously pluralistic." ${ }^{7}$ This statement follows an opinion he shares with Barret who "postulated that the phenomenological growth in African Christianity would weigh more in favour of 'younger' churches than the older Western ones," ${ }^{8}$ that is, the historic mission churches. "As this fight progresses", it is evident that, the omnipotence of historic Protestantism" and Roman Catholicism "is collapsing in the face of Pentecostal" and Charismatic growth in Ghana today and in Africa at large. ${ }^{9}$ Cephas Omenyo suggests that, this Pentecostal growth in Ghana, Africa and worldwide is the result of "new separate churches or massive loss of members to African Initiated Churhes (AICs), to Neo-Pentecostal or to Classical Pentecostal churches." 10 These Pentecostal churches do not exist just for a numerical growth only, but to some extent, for their interest in the prolefiration of churches in Ghana through the instrumentality of African breakaways which already post treat and fear on historic mission churches. ${ }^{11}$

The prolefiration of churches in Ghana today may suggest that some Christians would change churches like clothes. It is therefore possible that a person can be a member of more than one church. This phenomenon is noticeable among the youth. People join the local churches day in and day out. Some join these churches through evangelistic activities of various forms whiles others become members of the local church on their own.

This youth migration pathogen is gradually infecting the continent of Africa as some mission churches in West Africa continue to lose membership while the Pentecostal, Neo-Pentecostal and Charismatic churches have seen a surge in membership. ${ }^{12}$ The Church of Pentecost recently has seen an outburst in church growth with particular focus on the youth ministry. ${ }^{13}$ Even though the Presbyterian Church of Ghana among the mission churches recorded an appreciable upsurge in youth growth, ${ }^{14}$ the Methodist Church, Anglican Church and the Roman Catholic Church are facing youth migration, ${ }^{15}$ and subsequent low turnout of the youth to church services. How can this phenomenon (the movement of the youth from one church to another) be considered as church growth? What is responsible for this dichotomy? This article does not cover a detailed work of mainline, Pentecostals and Charismatics in Ghana. Rather, it attempts to proffer factors responsible for the migration trend and suggest remedies to tackle it.

\section{Youth and Ministry in Context}

Youth is the state or period of being young. This stage has been variously defined by many scholars. Youth is defined as the time period when one is young, between childhood and adulthood. ${ }^{16}$ Although some scholars do not concur with the various age limit proposed for youth, an appreciable percentage do accept the United Nations' proposal of 15 - 24 as the best suitable. ${ }^{17}$ The African Union in its Youth Charter designates a youth to be one between the ages of 15 and $35 .{ }^{18}$ In Ghana, a person is considered a youth if his or her age ranges between 15 - 35 years and they constitute $33 \%$ of the total populace. ${ }^{19}$

\footnotetext{
Emmanuel Kingsley Larbi, Pentecostalism: The Eddies of Ghanaian Christianity (Accra: CPCS, 2001), 34.

Victor Counted, "Youth in Pentecostal and Pharismatic Churches and Factors Accounting for their Attraction to Pentecostalism". A paper presented at the first Nigeria Pentecostal and Charismatic Research (NPCRC)Conference in May 2012 in Abuja. The conference was organized by Prof. Danny McCain of The NPCRC Centre, University of Jos, Nigeria. Any correspondence in respect to this paper should be sent to the author at connect@victorcounted.org, 1.

6 Asamoah-Gyadu, African Charismatics: Current Developments within Independent Indigenous Pentecostalism in Ghana (Netherlands:African Christian Press, 2005), 14.

Asamoah-Gyadu, African Charismatics 14.

Counted, "Youth in Pentecostal and Pharismatic Churches and Factors Accounting for their Attraction to Pentecostalism", 18.

9 Cephas N. Omenyo, Pentecost Outside Pentecostalism: A study of the Development of Charismatic Renewal in the Mainline Churches in Ghana, (Zoetermeer: Boekencentrum Publishing House, 2002), xiii- xiv.

11 Omenyo, Pentecost Outside Pentecostalism, xiv.

12 Matthews A. Ojo, “The Church in the African State: The Charismatic Pentecostal Experience in Nigeria," Journal of African Thought vol. 1. 2 (1998): 101.

13 Emmanuel Achim Gyimah, The Church of Pentecost: Yesterday, Today and Tomorrow (Accra: Journa Grafy Limited, 2013 ), 93.

14 Joseph Obiri Yeboah Mante and D. Aboagye-Danquah, eds., Presbyterian church of Ghana Synod Decisions and the Rational behind the Decisions, 1975 - 2000 (Accra: Adwinsa Publications, 2014), 163.

5 Ghanaian Chronicle, 28th June, 2013.

16 Albert Sydney Hornby, Oxford Advanced Learner's Dictionary of Current English (New York: Oxford University Press, 2000 ), 516.

17 UN Secretary-General's Report to the General Assembly, A/36/215, 1981.

18 Africa Youth Charter: Forum for African Women Educationalist,

http://www.africa-union.org/root/ua/conferences/mai/hrst/charter\%20english.pdf, accessed 20th May, 2019.

19 National Youth Policy http://www.mobileghanaweb.com, accessed 10th April, 2019.
} 
The youthful period is characteristic of freshness, vigour and lively spirit with underlying behavioural patterns. ${ }^{20}$ This youthful period presents a lot of challenges and crises to many of them. According to Kroger and her colleagues, many things change during adolescence and young adulthood. They see the youth as unstable, erratic and less religious unless influenced. ${ }^{21}$ It is therefore possible to see the youth migrate to different churches with a little influence or inducement from a friend or anybody.

Like every other human group, young people have their interests, likes and dislikes which must be strategically factored into programming by churches to get the best out of this group. Else, they will move towards the very source of attention and attraction where they feel their temporal and spiritual needs will be met or at least appear to be met. Immanuel Carl affirms that most youth follow their passions and relegate rationality into oblivion. ${ }^{22}$ The youth are not completely satisfied unless for a minimal period. They are also insatiable like every other human. ${ }^{23}$ For this reason, some youth do not actually consider their church denominations or affiliations when it comes to perusing their future goals such as pastoral ministry, jobs, marriage, and education and so on. It is possible to see the youth migrate from one church to another in fulfillment of any of these needs in life.

Currently, the context of youth ministry in many churches differ. Retaining the youth in mission churches has led to the establishment of various youth ministries so that the youth may stay. Some Ghanaian mission churches have always strived to keep up to date with events regarding young people even though for some churches, this quest presents a daunting challenge. In attempt to deal with these challenges, various strategies are employed by churches targeted towards revamping youth interest in their churches and to some extent stop youth migration as much as possible. ${ }^{24}$ Besides these strategies, it remains an undeniable fact that some youth from these mission churches still migrate to Pentecostal and Charismatic churches.

\section{METHODOLOGY}

This study adopted literature examination and interviews as the approaches for gathering of data for a qualitative enquiry. Qualitative approach allows the researcher to analyse, assess, discuss, explain, and explore the experiences, ideas and opinions of scholars and respondents on a particular issue under discussion. ${ }^{25}$ Three in-depth interviews were conducted with three church opinion leaders. Two of them were from two mission churches and one from a Charismatic church. The aim for this selective interview was to confirm the claim of youth migration in mission churches by some scholars. The interviews and discussions were documented and analysed with the findings from the literature study which forms the larger source of information that is applicable on the subject matter. The data was critically analysed thematically.

\section{FINDINGS AND DISCUSSION}

\section{The Growth of Pentecostalism/Charismatism in Ghana}

Francis Benyah has argued that Pentecostalism has grown to become the representative face of Global Christianity. This is as a result of the rise, growth and the influence of Pentecostal theological orientation that appeals to most cultures where the movement finds itself. Pentecostal beliefs and practices (theology) have always tended to influence and shape the daily lives of its members and consequently, produce a penchant for their rights and duties in the society or community where they find themselves. One reason Benyah observes that accounts for the "massive growth and expansion of the Pentecostal movement on the African continent is the relevance of the movement's theology which is contingent on its ability to address the particularities of the people's distinctive cultural and societal circumstances." ${ }^{26}$

\section{He further contends passionately that:}

Modern Pentecostalism in Africa is largely attributed by some to indigenous roots, the impacts of external interventions and spiritual flows especially from Western countries such as the United States of America cannot be denied scholars... Prior to the emergence of the contemporary Pentecostal/ Charismatic movement in the 1970s, there had been an avalanche of spiritual flares, some of which fed into the new forms.... Since its emergence in the 1970s and 80s, the Pentecostal movement has grown from the margins of African Christianity to the centre, making the Pentecostal movement the most dominant form of Christianity in Africa's religious landscape. The dynamism, vibrancy and vivacity of the new Pentecostal movement have changed the public face of Christianity and externalized its influence outside its domain.... Pentecostal style and culture have transcended beyond the walls of the church into the public sphere. Pentecostal ideas, beliefs and

\footnotetext{
20 Andy Furlong, Youth Studies: An Introduction (USA: Routledge, 2013), 2.

${ }^{21}$ Jane Kroger, Monica Martinussen and James E. Marcia, “Identity Status Change During Adolescence and Young adulthood: A meta-Analysis," Journal of Adolescence 33 no. 5( 2010): 686. https://doi.org/10.1016/j.adolescence.2009.11.002

22 The Dark Age of Christianity in Ghana, www.myjoyonline.com, accessed 11th May, 2019.

23 Abraham H. Maslow, Motivation and Personality, 2nd Ed. (New York: Harper and Rowe, 1970), 20.

24 Omenyo, Pentecost Outside Pentecostalism, 142.

25 Samuel B. Adubofuor, Department of Theology Research Writing Manual for Project Work and Dissertation ( Kumasi: Christian Service University, 2019$)$ : 13.

26 Francis Benyah, Pentecostalism and Development Discourse in Sub-Saharan Africa, Mission Studies, 36 (2019): 392.
} 
practices continue to shape the way adherents engage in social, cultural and political issues that affect them. ${ }^{27}$

The Pentecostal and Charismatic churches' ability to transcend beyond the boundaries of the church in Ghana is nevertheless dependent on the style of their worship and local initiatives which in a way seem appealing to their adherents particularly the youth. Cephas Omenyo has confirmed that in Ghana and elsewhere there is a "massive pentecostalization which is taking place in all churches worldwide, beginning with the music and the choruses and ending with new separate chuches."28

Asamoah Gyadu has observed further the historical backgroud of the growth and spread of the Pentecostal movement in Ghanaian Christian history. He notes three main indigenous Pentecostal waves that have dominated the Ghanaian religious Christian landscape. According to him, "the first wave of Pentecostal Christianity in Ghana, the Sunsum Sore, began in spontaneous response to the meteoric rise and parallel activities of a number of African prophets whose magnetic personalities and campaigns of revival and renewal drew masses into Christianity. In Ghana, these great religious stirrings began in 1914 with the visit to the coastal town of Axim of the 'Black Elijah' of West Africa, the Liberian prophet, William Wade Harris." ${ }^{29}$ The second wave of Ghanaian Pentecostal movement he described as Western Mission oriented Pentecostal denominations. According to him, "the second wave of Pentecostal Churches, the Western Mission-related Pentecostal denominations, have their roots in indigenous initiatives but became linked quite early with foreign Pentecostal missions." ${ }^{30}$

Lastly on the third wave, Asamoah-Gyadu writes that:

the third wave of Pentecostal Christianity currently enjoying enormous growth and influence in Ghana, as elsewhere in Africa, is the neo-Pentecostal movement. The expression 'neo-Pentecostal'is used here as an umbrella term to encompass Pentecostal renewal phenomena associated with trans-denomenational fellowships, prayer groups, ministries and independent churches which came into existence or prominence from about the last three decades of the twentieth century. In the Ghanaian context the historical reference is important, the neo-Pentecostal movement has a theological distinctiveness that is not as evident, at least not to the same degree, in the other versions of Pentecostalism. ${ }^{31}$

This insightful observations rightly suggest that the exponential Pentecostal and Charismatic growth and spread in Ghana is largely attributed to indigenous leadership and initiatives. Unlike the historic mission churches in Ghana whose leadership, operations and supervision was externalized, that is outside Ghana when they began missions, the Pentecostal and Charismatic churches however were internally influenced in terms of missions and leadership. That probably might have motivated and influenced the quick response and participation of many Ghanaians who joined these Pentecostal churches from the beginning.

The classical Pentecostals like Christ Apostolic Church, Assemblies of God and the Church of Pentecost started around the 1930s while the neo-Pentecostal or Charismatics ministries began around the 1970s and 1980s. ${ }^{32}$ Even though the classical Pentecostals and neo-Pentecostals movements may exist distinctively under denominations, however, in practice they both place emphasis on the pneumatic experience and expressions of every believer as a sign of a genuine conversion. "These churches have grown from the margins to the centre of Christianity in Ghana making it one of the mainline Christian groups in Ghana." ${ }^{33}$ What this means is that, like the mission churches, Pentecostals and Charismatic churches have spread all over Ghana with established mission stations, districts and branches in every region as well as abroad.

Another factor leading to the Pentecostal growth in Ghana in the Author's view is the 'leader/founder personality' influence. "In African religious movements the leader/founder, who is perceived to be a man or woman of sacred power, is held in awe and much religious activity may revolve around such persons. This tendency to refer to religious leadership is to some extent also present in sections of the Ghanaian neo-Pentecostal movements." ${ }^{34}$ This view may suggest that the personality of a religious leader plays a major role in the response, growth and spread of religious movements particularly Pentecostal and Charismatic Churhes as pointed out above. To some extent, some people may become a member of a religious movement or organization like a church because of the fame or influence of the founder. This is inline with Asamoah-Gyadu's view that from the first wave of Pentecostal movement in Ghana, a number of African

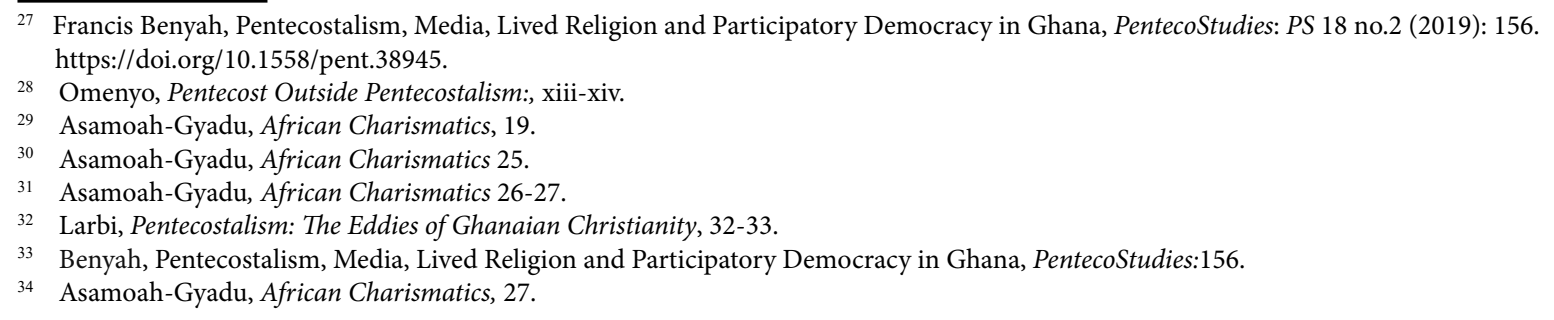


prophets used their magnectic personalities and campaigns of revivals and renewals to draw masses into Christianity. ${ }^{35}$ It is therefore an undenineable fact that the personality of a leader may determine the group or gender of people he may attract. A current trend of such innovative leadership style which has the ability to influence and attract the youth is what the Author terms as the "youth model leadership" 36 The emphasis on this kind of leadership is on the personality and age of the leader. It is argued that, some infant Pentecostal and Charismatic church leaders or founders are within their youthful age and the youth find these churches and their leadership appealing and worth following. ${ }^{37}$ The assumption with this ideology is that, such churches seem to understand the lifestyle, demands, needs and passions of the youth and are able to address them appropriately. It is therefore without doubt that many of the Ghanaian youth have found such Pentecostal and Charismatic churches adaptive, resulting in their wide spread in Ghana to the extent that almost every classroom in most of the schools in the cities are occupied by these churches.

The Ghanaian Pentecostal dynamism is another factor. Agreeing with some scholars regarding Pentecostal dynamism in its approach to the youth, Counted concludes that:

the great strength of the Pentecostal impulse" lies in "its power to combine its aptitude for the language, the music, the cultural artifacts, and the religious tropes of the setting in which it lives." This arrangement makes it possible to target the youth simply by operating within their context and speaking in their language-game compared to those that are professionally westernized - the mission mainstream churches. The appealing interface is irresistibly considered under the indigenized platform. ... one of the outstanding features of Pentecostals in the Third World is their religious creativity and spontaneously indigenous character which seems to have hugely drawn young people to their pews. Through this commitment to indigenization, Pentecostals have "tuned in with the language, concerns and hopes of the people" and connected to young people with steep affiliation that traditional churches might not render. From this comes the attraction of the youth and thus they broadcast an invitation to their friends, to come have their taste of freedom and connect to God as they are. ${ }^{38}$

This Pentecostal explosion in Ghana could not have been possible without these churches operating in the context of the youth. In that respect, the theological orientation of the Pentecostal and Charismatic churches, that is, by combining the language, traditional and comtemporary music, cultural artifacts and religious setting demonstrate the Pentecostal dynamism which made it possible for their messages to penetrate the hearts of the youth. Omenyo concludes that, "currently, the classical Pentecostal and neo-Pentecostal churches are the fastest growing Christian movements in Ghana" because they have adopted from African Independent Churches "certain popular traditional African forms of worship such as drumming, hand clapping and dancing." ${ }^{39}$

\section{Pentecostal/Charismatic Churches Attraction to Upwardly Mobile Youth}

Some observers have pointed out that many of the Christian youth are attracted to Pentecostalism and Charismatism in Ghana. Various reasons as discussed above in this paper suggest that the relationship between the youth and Pentecostalism/Charismatism is insuperable. To a large extend, the claims, assumptions, inspiration and projections of Pentecostalism appears to be youthful. There are several reasons or factors that may account for the undineable attraction of the youth to Pentecostalism and Charismatism in Ghana. Asamoah-Gyadu has outlined some identifying features of the Charismatic ministries which are currently adopted by other Pentecostal churches in Ghana. He observes the following:

a special attraction for Ghana's 'upwardly mobile youth'; a lay oriented leadership; ecclesiastical office based on a person's charismatic gifting; innovative use of modern media technologies; particular concern with church growth; mostly urbancentered congregations; a relaxed and fashion-conscious dress code for members; absence of religious symbolism in places of worship; English as the principal mode of communication; and an ardent desire to appear successful, reflect a modern outlook and portray an international image. ${ }^{40}$

Intrestingly, these features above portray the strength and dynamism of the modern day Pentecostal and Charismatic churches. They are framed or crafted to meet the need and desire of the youth in order to attract them to these Charismatic churches. Pentecostalism truly reflect the image of the youth. Obviously, the youth embrace modernism with the desire to lead, show their talents and gifts in public through the media platforms. In this study however, among the features noted above, the worship style and the use of modern media technologies of Pentecostal and Charismatic churches to attract the youth is further discussed.

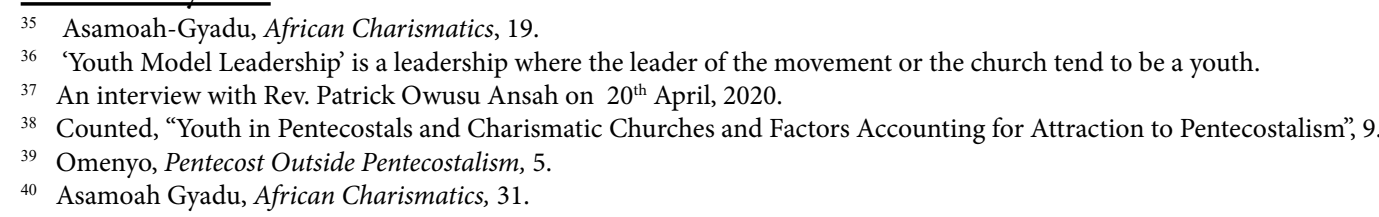




\section{Worship Style}

As observed above, the Pentecostal and Charismatic churches' in Ghana have developed a style of worship which attract the youth. What this means is that, the contemporary genre and tempo of Ghanaian music is gradually bringing some level of changes in the worship styles of these Pentecostal and Charismatic churches. This dynamic worship depict, project Pentecostalism and Charimatism and the youth can easily identify with. In this way the Ghanaian youth find Pentecostal and Charismatic style of whorship accommodative and adaptive. Without doubt, some Ghanaian youth throng Charismatic churches because of the flexibility of Pentecostal worship services which have provided them an alternative Christian culture. Their worship is contextual because it addresses the felt needs of the youth. They are able to attract the youth and retain them thus making their faith relevant through their motivational worship and other social activities organized in their church services.

These motivational and innovative worship styles coupled with their social activities are crafted and framed in various forms. In Pentecostal worship, it appears there is greater freedom of action or movement (clapping, jumping, dancing, shouting,) spontaneity ("I receive it", "I claim it", "saying amen", screening) than one sees in most historic mission churches where the service is formal with restrictions on movement. From this perspective, Pentecostal worship is more participatory or inclusive than exclusive as seen in mission churches. Pentecostal worship turns to offer a more contemporary reformed Christian worship that allows movement than one finds in the historic mission churches. The Christian youth of today is more adaptive to experiential Christianity than liturgical traditional modelled Christianity which in their view, may be hypocritical, ritualistic, empty and devoid of God's true presence. ${ }^{41}$ For some African Pentecostal/Charismatic youth, one major challenge they have had with historic mission Christianity is the seemingly virtual emptiness of its worship. Currently, however, the above observation can be said to be flawed and misleading as the situation has changed as most of the historic mission or established churches have adopted the Pentecostal/Charismatic style of worship into their liturgy. However, Omenyo observes that regardless of traditional denominational boundaries, Pentecostal/Charismatic fire continue to spread like a wide bush fire, ${ }^{42}$ probably through its worship innitiatives. ${ }^{43}$

Apparently, a new trend of Pentecostal/Charismatic worship initiative which targets the youth in Ghana is 'Christian worship concerts'. Without doubt, the effect of music on an individual be it religious or secular cannot be undermined. Worship concert is one of the strategic means by which many neo-Pentecostal churches use to propagate the gospel, win souls for Christ particularly the youth through the power of the Holy Spirit. This approach is also known as 'musical evangelism. ${ }^{44}$ These worship concerts are stratetigically and stylistic organized with highly regconised Christian musicians. To this end, many gospel awarding artistes in contemporary times have partnered some of these Pentecostal/charismatic churches to host a number of worship concerts in their churches and even in many tertiary institutions where the youth are mostly found. A typical example is 'Worshippers Cry' which has become an annual progromme in Christian Service University College where popular gospel artistes are invited to thrill students with gospel songs. This strategy has often drawn a lot of youth closer to Christ. ${ }^{45}$ White and Niemandt also observe that Joyful Way Incorporated has journeyed all through Ghana, in cities, villages, public places, educational institutions, churches, on radio and television, and where non-Church youth could be found. Music evangelism became popular in Ghana through the pioneering work of this group. ${ }^{46}$ While in school, White and Niemandt had the "opportunity to witness how Agape Incorporated used music and drama to bring people to Christ whilst he was in high school at Osei Tutu Senior High School in Akropong, Kumasi (Ghana). On that day many of the young men on campus gave their lives to Christ because the Holy Spirit ministered to them through that performance." ${ }^{47}$

In recent times there have been more of these Pentecostal/Charismatic worship concerts organized by some of these churches in various forms. Popular amongst these concerts in Ghana include Ohemaa Mercy's 'Tahilla Worship', Nquebeko Mbatha's 'Absolute Worship' and 'Harvest Praise' by Harvest Chapel International. ${ }^{48}$ As a matter of fact, most of the informative observations made during such worship concerts explain the fact that the youth will always want to join and remain in churches with a 'charged atsmostphere. Notably, the participation of the youth in such Pentecostal/ Charismatic 'worship and praise' gatherings underscore the relevance and the interpretation of these worship concerts to the Pentecostals/Charismatics and the Ghanaian Christian youth.

\footnotetext{
41 Joseph Kwabena Asamoah-Gyadu, "Signs of the Spirit; Worship as an experience in African Pentecostalism" Journal of Africa Christian Thought vol 8. 2(2016): $10-22$.

42 Omenyo, Pentecost Outside Pentecostalism, 84.

43 Omenyo, Pentecost Outside Pentecostalism, 84.

44 Sellas Manna, 2017 in Retrospect: Unforgettable Gospel Events and Concerts that characterized the year. https://www.worshippersgh.com published on $31^{\text {st }}$ December, 2017 accessed on $8^{\text {th }}$ July, 2020.

45 Daniel Aboagye Aryeh, Assessing the Role of Prophecy in mission in Charismatic Christianity in Ghana: An Exegesis of 1 Corinthians 14:24-25. Accra: Missiological Society of Ghana, 2018.

46 Peter White and Cornelius Johannes Petros Niedmant, “Ghanaian Pentecostal Churches' Mission Approaches”, Journal of Pentecostal Theology, vol 24. 2(2015): 254. https://doi.org/10.1163/17455251-02402010

47 White and Niedmant, “Ghanaian Pentecostal Churches' Mission Approaches” 254.

48 Manna, 2017 in Retrospect.
} 


\section{Use of Modern Media Technologies}

Francis Benyah has argued that following the adoption of the 1992 Constitution which permits the privatization and democratization of the Ghanaian media, has paved the way for the purchase of airtime by some private individuals and institutions, especially Pentecostal/Charismatic churches, to carry their message to the masses. Citing Meyer and Asamoah-Gyadu, Branya agrees to the fact that the use of social media has become a life style and a major platform through which Pentecostal and Charismatic churches sell and project their faith, ideas and practices into the public sphere. He notes that their engagement on the media started since their inception in the early 1970s and their media "broadcasts have extended sacred spaces into public sphere, thereby colonizing the public space with their presence". ${ }^{49}$ Through the extensive use of modern media, Pentecostal/Charismatic churches "articulates precisely their public presence with the motive of converting the public space into a Christian environment". ${ }^{50}$ The Pentecostal dominance, presence and practice on the media among Charismatic churches in Ghanaian Christianity in a way, seeks to describe a new form of Pentecostal theological orientation in reaching out to the youth.

Significantly, the advent of information and communication technology did not only benefit the secular world, but also the church and, for that matter, mission and evangelism in Ghana. ${ }^{51}$ The Media, both electronic and social have become effective channels for some Neo-Pentecostal churches in reaching a wider audience and in the context of this study, the youth. Primarily, the youth represents a greater number of people who use the radio, television, cell phone and social media; facebook, twitter, whatsapp, instagram and many others. What the youth have in common with Pentecostals/Charismatics in this context is their adept use of modern media technologies where their challenges are spiritually addressed.

Recently, the era of COVID 19 has actually tested the Ghanaian churches perspectives and capacities to use the media for spiritual services. In the wake of COVID 19, radio, television and facebook have become the virtual church room and pulpit through which many church services are transmitted to congregants of these neo-Pentecostal churches. This phenomenon has made some of these Pentecostal and Charismatic churches influential and popular in Ghana today. Some mainline and classical Pentecostal churches that is, Church of Pentecost, the Baptist Church, Assemblies of God and many others are actively using these media channels to share the word which hitherto was not the case.

The media and the internet have become a virtual community for business, governance, education, religion and others to thrive. Campbell points out that, the internet and social media have allowed Christians to find new means of exploring their faith and to chat and share different faith-related issues. He explains that religious activities such as worship and missionary work can be done online. ${ }^{52}$ Brawner concludes that, "if the church is to effectively reach this sight and sound generation for Christ, it must utilize the same media roads much more than what the society is using every day". ${ }^{53}$ It is important to state that any church that adapts and positions itself for the media approach to missions is likely to be attracted to the youth at large.

\section{New/Current Factors Accounting for Youth Migration to Pentecostal/Charismatic Churches}

According to Omenyo, "the rise of the various streams of Pentecostal/Charismatic movements in Ghana, was mainly due to the alleged lack of dynamic manifestation of the Spirit of God in the mainline churches; their lack of concern for practical and existential issues, both physical and spiritual, that confront membership; and generally poor pastoral care." ${ }^{54}$ While this view affirms the reasons for the emergence of these movements in Ghana, nevertheless, it also points out reasons for the massive exudosing of the youth from the historic mission churches recently. The following may find affirmation and expression in Omenyo's view above as current factors accounting for youth migration to Pentecostal/ Charismatic churches in Ghana.

\section{Ignoring the Needs of the Youth in Mission Churches}

Taylor notes that the needs of people are broadly divided into five; Survival, Security, Belonging, Esteem and Fulfilment needs. Survival needs are the physical needs - food, clothing and shelter. Security needs are the needs for safety and order, to be able to live without being afraid of enemies. Belonging need is the need to belong to a group. Esteem need is the need to be respected and needed by other people. Fulfilment need is the ability to achieve the purpose of God

\footnotetext{
49 Benyah, "Pentecostalism, Media, Lived Religion and Participatory Democracy in Ghana", 3.

50 Benyah, "Pentecostalism, Media, Lived Religion and Participatory Democracy in Ghana", 3.

51 Michael Pocock G. Van Rheenen, and D. McConnell, The Changing Face of Missions: Engaging Contemporary Issues and Trends (Grand Rapids, MI: Baker Books, 2005), 299.

52 Helland Campbell, \& P. Calderon, The Question of Christian Community Online: The Case of the Artist World Network', Studies in World Christianity 13(3), (2007): 261-277.

53 Jeff Brawner, 'Meeting and Using the Media', in T.E. Trask, W.I. Goodall, and Z.J. Bicket (eds.), The Pentecostal Pastor: A Mandate for the 21 ${ }^{\text {st }}$ Century (Springfield, MO: Gospel Publishing House, 1997), 369.

54 Omenyo, Pentecost Outside Pentecostalism, 98.
} 
for one's life. Fulfilment need also includes a Spiritual need to have a relationship with God. ${ }^{55}$ Counted argues that "a major share of the factors responsible for attracting youths to Pentecostalism seem to come as a result of a longing - "for relationship, mystery, experience, passion, wonder, creativity, and spontaneity". ${ }^{56} \mathrm{He}$ observes that many youth yearn for something new from these traditional churches. As a result, they dislike their traditional-repressive church condition $s^{57}$ and become more adventurous in exploring new spiritual opportunities in other churches.

It appears some of these needs are ignored by mainstream church leadership. It is important to note that the youth ministry is holistic and comprehensive. Therefore, the leadership of mission churches should not take any of these needs for granted. The implication here is that, a church that ignores the needs of its youth will have itself to blame. These needs may be physical, spiritual, social or psychological. Physical needs are basic human needs for survival. To meet the spiritual needs of the youth, there is a lot of challenge as these are related to the supernatural like evil forces, spiritual satisfaction, spiritual power and authority. This is very important in Africa, where religion is seen as the opium of the masses, making the African notoriously religious. ${ }^{58}$ It is worth stating that, any church that deliberately or mistakenly disregards the emotional, psychological, social and spiritual needs of its youth suffers the penalty of massive migration in favour of a church that fulfills these needs. In Gyeke's view, all that a church needs is concerted and targeted collaboration to equip the youth with both the physical and the spiritual needs may strengthen youth loyalty to a particular denomination. ${ }^{59}$

\section{Peer Pressure}

The youth, at one time or the other, may have to leave home for school. This change in residence comes up with its own challenges, one of which is the intense pressure gullible youth are subjected to in their quest for academic and vocational knowledge. Luhrmann suggests that this exposure, affects their commitment to God and church as well." ${ }^{\circ 0}$ In some cases these young people start committed but end up losing commitment. Travis Kaiser suggests that students, who were formerly Catholics, leave the church because of this exposure ${ }^{61}$ It is possible that some students may end up going along with their friends instead of returning to the mission or mainstream churches they were born into.

Commenting on peer pressure as a factor leading to youth migration to Pentecostal churches, Counted observes that: With such an unusual perspective of church, the youth is lost in enthusiasm and gripped in eagerness to see what their friends' church has to offer. Then, they plan a visit outside the supervision of their guardian, to see the hotly advertised church. They visit; stunned by what they see, gazed upon by younkers they admire, they socialize in a manner they have never seen. For them, that Sunday worship experience, marked by their juvenile understanding of "freedom" and watered by the church's innovative excellence and display of youths' projects, becomes a blast for them. This will be an unforgettable experience for the youth. Thus the youth are enveloped with a mere wish of membership only to realize that their parents will be waiting back at home to know their whereabouts. The youth is then addicted to the Pentecostal phenomenon and revisit their "friends" church again and again - once they see an opportunity - until they graduate from home-pets to homefree-adults. This when they invest their time and energy in membership, to function and integrate fully into Pentecostalism. They forget their home church in no estimated time frame. ${ }^{62}$

Charles Gyamfi admitted that some youth migrate to new churches for a myriad of reasons including looking for signs and wonders. Being pressured by their friends in the second-cycle schools and at the tertiary level, getting bored with some procedures in the mission churches like worship styles, hymns and so on, they integrate fully into their friends church for a new theological experience. He however noted that, if the right reforms are made by leadership in mission churches, the trend will be reversed in no distant time. ${ }^{63}$

\section{Static Church Leadership}

Some mission churches have leadership which could be described as 'not in touch with the times.' Such leaders do not possess emotional intelligence to decipher the mood and the demands of the time. Some may even see the demands of the young people or the youth as ungodly or immoral. For instance, when the Church of Pentecost decided to relax its policy on youth dressing, there were some dogmatic pastors who opposed the motion, to the point of affray, and vowed never to accept it, even though the policy revision does not infringe on sound theology. ${ }^{64}$

\footnotetext{
Harold Taylor, Tend My Sheep (London: Society for Promoting Christian Knowledge, 1983), 39-40.

56 Counted, "Youth in Pentecostal and Pharismatic Churches and Factors Accounting for their Attraction to Pentecostalism", 20.

7 Counted, "Youth in Pentecostal and Pharismatic Churches and Factors Accounting for their Attraction to Pentecostalism"20.

John S. Mbiti, African Religions and Philosophy, 2nd Revised Ed., (Oxford: Heinemann Educational Publishers, 1989 ), 1.

Kwame Gyekye, African Cultural Values: An Introduction, (Accra: Sankofa Publishing Company, 1996), 55.

Tanya Luhrmann, When God Talks Back: Understanding the American Evangelical Relationship with God (Massachusetts: Vintage, 2012 ), 36.

Travis Kaiser, A Comparative Analysis of the Church Retention Rate of Christian High School Graduates (New York: Routledge, 2015), 26.

Counted, "Youth in Pentecostal and Pharismatic Churches and Factors Accounting for their Attraction to Pentecostalism", 9.

3 An interview with Rev. Father Charles Gyamfi of Anglican Church in New Offinso, the Christ the King, Parish on 12 $2^{\text {th }}$ April, 2019.

4 Sam Mark Essien, “Blows In Pentecost Over Dress Code”, Daily Guide, February 19, 2010, 3.
} 
Again, the measure of youth disaffection with church rituals and liturgy is a crucial factor. Asamoah-Gyadu suggests that there may be dullness and lack of vitality in some mission churches fuelling the massive youth drifts from the mainstream churches. ${ }^{65}$ Perhaps, some strategies may be out-dated and counter-productive as the drift by the youth of the church has increased its tempo. Activities approved by the church leadership to invigorate the youth and sustain their interest in the liturgy, dogma and practices of the Church may be achieving little. A student of Polish origin was honest to admit that she did not reject the Catholic Church but that it was the church that rejected her. ${ }^{66}$

\section{Socio-Economic Factors}

Majority of persons living on the African continent are poor. In a recent study, researchers opine that behind some of the causes of abject poverty in the country is the culture and that majority of black Africa suffers from poverty with families living on less than two dollars daily. ${ }^{67}$ The implication is that quite a number of Ghanaians are poor and the youth are caught up in this canker as well.

To some extent, socio-economic factors drive people to church. Unemployment, indigence, wealth acquisition, ill health, migration-related quests, emotional issues, generational curses, marital squabbles, prolonged spinsterhood and heartbreaks are some socio-economic issues that must be addressed by the Church if the Church intends to halt the exodus of its youth. With nearly one in every five youth unemployed, ${ }^{68}$ the quest to move to a "solution centre" is intense, real and tantalizing. Some neo-Charismatic and Pentecostal pastors in Ghana capitalize on socio-economic factors and bait the less privileged, unemployed and poor by donating large amounts of money and food to alleviate their plights. ${ }^{69}$ These churches are seen as heaven for persons socially and financially challenged, most of whom fall in the youth category.

Another challenge is that some young people are not hungry for the good news anymore; they want prosperity, miracles and profitable business contacts from churches. This explains why a poor youth who has been ejected by his or her landlord would move to some self-acclaimed prophets and accredited churches to appreciate lotto numbers ${ }^{70}$ and some "luck money" for sustenance. Currently, it appears some Ghanaian youth have joined a number of neo-Pentecostal and Charismatic churches in the search for prosperity, fortune, luck, marriages, cure for ailments and insatiable desire for things ephemeral. ${ }^{71}$ George Amoah is of the view that the reasons for drift is multifaceted, ranging from pettiness to penury. There are a lot of attractions out there and that young people are mostly vulnerable. These well packaged attractions purposely target the youth, making them drift to newer fellowships and denominations that advertise these attractive offers. ${ }^{72}$ Nonetheless, he noted that the situation in the mission churches is not a hopeless one. He is upbeat that these mission churches will devise practical strategies to reverse the trend and re-align the young people to attend regularly and participate fully and dutifully when the opportunity presents itself. ${ }^{73}$

\section{Youth Migration and its Implication for Mission Work in Pentecostal/Charismatic Churches and Historic Mission Churches \\ Involve the Youth in all Church Activities}

Mission Churches need to involve the youth in reaching out to the youth. Unfortunately, the level of involvement in some mission churches may be described as dictatorship. Some do not engage their youth in strategic church discussions at all. Counted has noted that "Whereas what traditional churches offers to get involved are organized by the leader of the congregation and have a very obligatory character, the events organized by young people themselves are less binding and often without an obvious traditional appearance. Consequently, people from a non-Pentecostal background feel attracted to the latter." ${ }^{\prime 4}$ It is possible for the leadership of mission churches to collaborate with their youth in building strong churches.

The days when young people were treated as spectators are long gone. The challenge is that if the youth are not valued in the church of today, they will not be around to be the church of tomorrow. Mission churches must strive to

\footnotetext{
65 John Kwabena Asamoah-Gyadu, Contemporary Pentecostal Christianity: Interpretations from an African Context, (Ghana: Regnum Africa, 2013 ), 32.

${ }_{66}$ Slawomir, Mandes and Maria Rogaczewska, "How Twenty - and - Thirty - Somethings in Poland Re-evaluate Their Religions,"Journal of Contemporary Religion 28 no.2 (2013): 261.

67 Julius Ofori Kwasi, "Why Most African Countries are Poor" Arts and Social Sciences Journal, 9, no.1 (2018): 5.

68 United Nations Department of Economic and United Nations Department of Public Information, The Millennium Development Goals Report 2009 (Washington: United Nations Publications, 2009), 108.

69 Innocent Okonkwo, “TB Joshua Makes Case for the Needy," All Africa, 15th June, 2010.

70 "No Theology Degree, no Church," Daily Graphic, No. 20692, Monday, 28th May, 2018, 53.

71 Cecil M. Robeck, “An Emerging Magisterium? The Case of the Assemblies of God, Pneuma," The Journal of the Society for Pentecostal Studies, 25(2), (2003): 183. https://doi.org/10.1163/157007403776113224

72 An interview with Pastor George Asamoah on the 23 $3^{\text {rd }}$ of May, 2020.

73 An interview with Pastor George Asamoah on the $23^{\text {rd }}$ of May, 2020.

74 Counted, "Youth in Pentecostal and Pharismatic Churches and Factors Accounting for their Attraction to Pentecostalism", 9.
} 
mobilize every member for ministry including the youth. The youth involvement in mission activities is apt because the youth are listed as the group that needs evangelism most and that they are the most capable in evangelizing to themselves. ${ }^{75}$ Enhancing youth involvement in mission churches demands strong relationship between the youth and leadership.Affirming Vandenberg's view on youth ministry in mission churches, Victor Counted observes that:

the "fall" of mainstream churches even as they operate a traditional youth ministry: "...youth ministry, as we know it, is a construct of an era being superseded by different values and a new set of challenges. Traditional youth ministry will not serve the future church in postmodern times effectively. Youth ministry of today, as we must have observed from... must be a construct of different dynamics. Relationships need to get deeper, be tolerant and, in most cases, flexible. Sincerely speaking, many churches have no real relationships with their youths. "Young people now are driven by relationships and by a real experience of life and faith. ${ }^{76}$

It appears the challenge of involving the youth in mission churches is not about allowing them to do what they want, rather, building a deeper relationship with the youth. It may be argued that without proper relationship between the 'young and the old' in mission churches, the future of youth ministries may suffer further youth migration and at large, a decline in church growth.

In fact, the Church need the youth in reaching out to the youth outside the church. The youth position of the Church of Pentecost for instance, affirms this. The church has recorded steady growth in youth membership for some years now. Pastor Emmanuel Aboagye Arko points out that the membership and leadership have strategic plans to sustain the growth and possess the Nations. According to him, the church announces its 5-year strategic vision on "possessed the Nations" and he was hopeful that the youth of the church are in the frontline for the realization of this dream codenamed Vision 2023 which strategically attempts to further increase youth membership. He stressed that the church is missional and has its focus on the Great Commission. Every member is involved. The aged is involved. The child in the Sunday school is involved. The youth is involved and in fact, in the frontline. ${ }^{77}$ No wonder the youth membership The Church of Pentecost keeps increasing week by week, month by month and year by year. Mission churches in Ghana should strategically find a relational dimension of involving the youth.

\section{Church Leadership Must be Dynamic}

Man currently lives in a very dynamic society. The leadership of mission churches in Ghana should demonstrate high level of dynamism in order to reach out to and sustain the interest of the youth in the ministry. The youth do not like boredom; in fact, no one does! Some form of radical dynamism must be injected into Christian service to hold the attention of young people, lest the drift. Gifford observes that for the neo-Pentecostal and Charismatic Churches, the growth has been mainly due to well-coordinated youth evangelism and these churches reciprocate the gestures by offering jobs to the youth ${ }^{78}$ and by extension meeting their spiritual and temporal needs. Similarly, Quartey emphasizes that church service is not only about the pulpit but also the role the young people are playing in terms of sound management, video projections and even the music ministry. ${ }^{79}$ There is dynamism in such churches. The implication therefore is that preaching the gospel to the youth must go along with the hopes and aspirations of the youth. ${ }^{80}$

\section{Technology and Vibrancy}

Mission churches must understand the period the church is in. That times have changed, is not in doubt. A new generation has been born. Modern technology, internet and explosion in information technology offer hope to them in this century. It is important to note that, following the outbreak of the coronavirus pandemic in Ghana, the ban on churches services tested and proved the significance of the use of technology in churches. Not until recently, some mission churches in Ghana did not see need to employ technology in advancing the gospel. The fact however remains that, four out of every five people or youth use social media around the world. ${ }^{81}$ The use of social media in persuading young people to come to church is significantly beneficial and well documented. ${ }^{82}$ To convert young people there is the need to tailor the good news relevantly for the youth through the appropriate channel. This is exactly what mainstream Churches should

\footnotetext{
75 Robert McNamara, "Youth to Youth Mission," The Furrow Stable 47, No. 2 (1996): 561

76 Counted, "Youth in Pentecostal and Pharismatic Churches and Factors Accounting for their Attraction to Pentecostalism", 11-12.

77 Graphic.com.gh, "The Church of Pentecost Unveils 5-year Strategic Vision" 13th November, 2018

https://www.graphic.com.gh/news/general-news/the-church-of-pentecost-unveils-5-year-strategic-vision.html, accessed May 2, 2019.

78 Paul Gifford, Ghana's New Christianity Pentecostalism in a Globalizing African Economy, (London: Hurst, 2004$), 61$.

79 Joseph Charles Quartey, The Youth And The Numerical Growth Of The Ga Presbytery In The Presbyterian Church of Ghana (MPhil Thesis, University Of Ghana, Legon, 2016), 69.

80 Isaac Atuobi Nyarko, Presbyterianism in Ghana from 1978 to 2013: Responding to the Existential Needs in the Kwahu Presbytery (MPhil Thesis, Kwame Nkrumah University of Science and Technology, Kumasi, 2016), 88.

81 Tom. Standage, Writing on the Wall Social Media - The First 2,000 Years, (London: Bloomsbury, 2013 ), 6.

82 Audrey Lim, "Effective Ways of Using Social Media: An Investigation Of Christian Churches In South Australia," Christian Education Journal Series 3, 14 no. 1 , (2017): 25.
} 
provide ${ }^{83}$ because, it is what the new generation yearns for. The following phrase that captures the generational thought succinctly is worth repeating: "The problem is that if the youth are not valued in the church of today, they will not be around to be the church of tomorrow." ${ }^{44}$ The implication is that the young people will drift. They will look elsewhere. The Orthodox and mainstream Protestant Churches will be depleted.

\section{RECOMMENDATIONS}

The following are recommended after a careful discussions:

- The youth groups in Mission Churches should be functionally involved by the leadership in the plans and activities of their churches. Mission Churches with few youth groups must devised strategies to task the youth with church activities and programmes to sustain their interest. It is impotant that the youth groups in Mission Churches organize evangelism, skills and vocational training, workshops, recreation, 'worship nights' and fun games periodically with the youth in mind.

- By virtue of emotional intelligence, concerted efforts must be made by Mission Churches welfare and counselling teams to meet the various needs of their youth.

- The leadership of Mission Churches for instance, must train and empower their youth on how to incorporate modern technology in their worship and services.

- It is also recommended that the leadership of Pentecostal and Charismatic Churches, as well, need to sustain the gains made so far and continue to press forward for more youthful souls by the use of more advanced technology.

\section{CONCLUSION}

Tailoring messages to suit the youth is key in their retention in mission churches because this is the gap targeted and filled by the neo-Pentecostal and Charismatic Churches. It is pertinent that church leadership especially mission churches adopt modern technology in an ambience of dynamism and pragmatism. In this way the drift of young people can be checked if the messages are relevant and technology modernized.

\section{ABOUT AUTHORS}

Paul Kang-Ewala Diboro is a Lecturer, Department of Theology, Christian Service University College, Kumasi Ghana. He is also the Pastor of Church Obuasi, Ghana.

Raymond Charles Ehiem (Rev), Great Change Christian Centre, Adenta, Accra and St. Patrick's Hospital, Offinso, Ashanti Ghana.

\section{BIBLIOGRAPHY}

Achim Gyimah, E. The Church of Pentecost: Yesterday, Today and Tomorrow. Accra: Journal Grady Limited, 2013.

Adubofuor, S. B. Department of Theology Research Writing Manual for Project Work and Dissertation

(Kumasi: Christian Service University, 2019): 13.

Africa Youth Charter: Forum for African Women Educationalist, accessed May 20, 2019.

http://www.africa-union.orgroot/ua/conferences/mai/hrst/charter\%20english.pdf

Aboagye Aryeh, D. Assessing the Role of Prophecy in mission in Charismatic Christianity in Ghana: An Exegesis of 1

Corinthians 14:24-25. Accra: Missiological Society of Ghana, 2018.

Asamoah-Gyadu, J. K. Contemporary Pentecostal Christianity: Interpretations from an African Context. Ghana: Regnum Africa, 2013.

.African Charismatics: Current Developments within Independent Indigenous Pentecostalism in Ghana,

Netherlands:African Christian Press, 2005.

.African Charismatics: Current Developments within Independent Indigenous Pentecostalism in Ghana.

Natherlands: Africa Christian, 2005.

. "Signs of the Spirit; Worship as an experience in African Pentecostalism". Journal of Africa Christian Thought

vol 8. 2(2016).

Brawner, J. 'Meeting and Using the Media', in T.E. Trask, W.I. Goodall, and Z.J. Bicket (eds.), The Pentecostal Pastor: A Mandate for the 21 ${ }^{\text {st }}$ Century. Springfield, MO: Gospel Publishing House, 1997.

\footnotetext{
83 Asamoah-Gyadu, Contemporary Pentecostal Christianity-Interpretations from an African Context, 61.

84 Thom Rainer, 9 Changes Dying Churches must make Immediately www.outreachmagazine.com/features/22510-dying churches-2.html, accessed 15th May, 2019.
} 
Benyah, F. Pentecostalism, Media, Lived Religion and Participatory Democracy in Ghana, PentecoStudies: [PS 18.2 (2019): 156. https://doi.org/10.1558/pent.38945.

Pentecostalism and Development Discourse in Sub-Saharan Africa, Mission Studies, 36 (2019): 392.

Cafferata, G. "Respect, Challenges, and Stress among Protestant Pastors Closing a Church: Structural and Identity

Theory Perspectives," Pastoral Psychology vol 66. 3 (2017) https://doi.org/10.1007/s11089-016-0751-z

Campbell, H. \& Calderon, P. The Question of Christian Community Online: The Case of the Artist

World Network', Studies in World Christianity 13(3), (2007).

Counted, V. "Youth in Pentecostal and Charismatic Churches and Factors Accounting for their Attraction to

Pentecostalism”. Pentecostal and Charismatic Research (NPCRC)Conference - Abuja (May 2012).

Donald, K. M. More Presbyterian Questions, More Presbyterian Answers: Exploring Christian Faith. Westminster John Knox Press, 2011.

Essien, S. M. "Blows In Pentecost Over Dress Code”, Daily Guide, February 19, 2010, 3.

Furlong, A. Youth Studies: An Introduction. USA: Routledge, 2013.

Ghana Web "The Dark Age of Christianity in Ghana," May 1, 2018. Accessed 11th May, 2019.

https://www.ghanaweb.com/GhanaHomePage/features/The-Dark-Age-of-Christianity-in-Ghana-647788

Gifford, P. Ghana's New Christianity Pentecostalism in a Globalizing African Economy. London: Hurst, 2004.

Gyekye, K. African Cultural Values: An Introduction. Accra: Sankofa Publishing Company, 1996.

Graphic.com.gh, "The Church of Pentecost Unveils 5-year Strategic Vision"

https://www.graphic.com.gh/news/general-news/the-church-of-pentecost-unveils-5-year-strategic-vision.html

November 13th, 2018, accessed May 2, 2019.

Hornby, A. S. Oxford Advanced Learner's Dictionary of Current English. New York: Oxford University Press, 2000.

Kaiser, T. A Comparative Analysis of the Church Retention Rate of Christian High School Graduates. New York: Routledge, 2015.

Kroger, J, Martinussen, M and Marcia, J. E. "Identity Status Change During Adolescence and Young adulthood: A metaAnalysis," Journal of Adolescence vol 33.5 (2010). https://doi.org/10.1016/j.adolescence.2009.11.002

Larbi, K. E. Pentecostalism: The Eddies of Ghanaian Christianity. Accra: CPCS, 2001.

Lim A."Effective Ways Of Using Social Media: An Investigation Of Christian Churches In South Australia," Christian Education Journal Series 3, Vol. 14, No. 1, (2017).

Luhrmann, T. When God Talks Back: Understanding the American Evangelical Relationship with God. Massachusetts: Vintage, 2012.

Manna, S. "2017 in Retrospect: Unforgettable Gospel Events and Concerts that characterized the year." $31^{\text {st }}$ December, 2017 Accessed on $8^{\text {th }}$ July, 2020. https://www.worshippersgh.com

Mante, J.O. Y. and Aboagye-Danquah D., eds., Presbyterian church of Ghana Synod Decisions and the Rational behind the Decisions, 1975 - 2000. Accra: Adwinsa Publications, 2014.

Maslow, H. A. Motivation and Personality, 2nd Ed. New York: Harper and Rowe, 1970.

Mbiti, S. J. African Religions and Philosophy. 2nd Revised Ed., Oxford: Heinemann Educational Publishers, 1989.

McNamara R. "Youth to Youth Mission," The Furrow Stable 47, No. 2 (1996).

National Youth Policy http://www.mobileghanaweb.com, accessed 10th April, 2019

"No Theology Degree, no Church," Daily Graphic, No. 20692, Monday, 28th May, 2018.

Nyarko, I. A. Presbyterianism in Ghana from 1978 to 2013: Responding to the Existential Needs in the Kwahu Presbytery. MPhil Thesis(Unpublished), Kwame Nkrumah University of Science and Technology, Kumasi, 2016.

Ofori J. K. "Why Most African Countries are Poor," Arts and Social Sciences Journal, 9, no.1 (2018).

Ojo, A.M. "The Church in the African State: The Charismatic Pentecostal Experience in Nigeria," Journal of Africa Thought vol. 1.2 (1998): 101.

Okonkwo, I. “TB Joshua Makes Case for the Needy," All Africa, 15th June, 2010.

Omenyo, C. N. Pentecost Outside Pentecostalism: A study of the Development of Charismatic Renewal in the Mainline Churches in Ghana, Zoetermeer: Boekencentrum Publishing House, 2002.

Pocock, M., Van Rheenen G. and McConnell D. The Changing Face of Missions: Engaging Contemporary Issues and Trends. Grand Rapids, MI: Baker Books, 2005.

Standage, T. Writing on the Wall Social Media - The First 2,000 Years. London: Bloomsbury, 2013.

Taylor, H. Tend My Sheep. London: Society for Promoting Christian Knowledge, 1983.

United Nations Department of Economic and United Nations Department of Public Information, The Millennium Development Goals Report 2009. Washington: United Nations Publications, 2009.

Warren, R. The Purpose Driven Church: Growth Without Compromising Your Message and Mission. Kaduna, Nigeria: Zondervan Publishing House, 1995. 
Quartey, J. C. The Youth And The Numerical Growth Of The Ga Presbytery In The Presbyterian Church Of Ghana. MPhil (Unpublished) Thesis, University Of Ghana, Legon, 2016.

Rainer, T. 9 Changes Dying Churches must make Immediately Accessed May 15, 2019. www.outreachmagazine.com/features/22510-dying churches-2.html

Robeck, C, M. "An Emerging Magisterium? The Case of the Assemblies of God, Pneuma," The Journal of the Society for Pentecostal Studies, 25(2), 2003. https://doi.org/10.1163/157007403776113224

Slawomir, M. and Rogaczewska, M. "I don't reject the Catholic Church-the Catholic Church rejects me": How Twenty- and Thirty-somethings in Poland Re-evaluate their Religion,"Journal of Contemporary Religion vol 28. 2 (2013). https://doi.org/10.1080/13537903.2013.783338

UN Secretary -General's Report to the General Assembly, A/36/215, 1981.

White, P. and Niedmant, C.J.P. "Ghanaian Pentecostal Churches' Mission Approaches”, Journal of Pentecostal Theology, vol 24. 2(2015): 241-269. https://doi.org/10.1163/17455251-02402010 